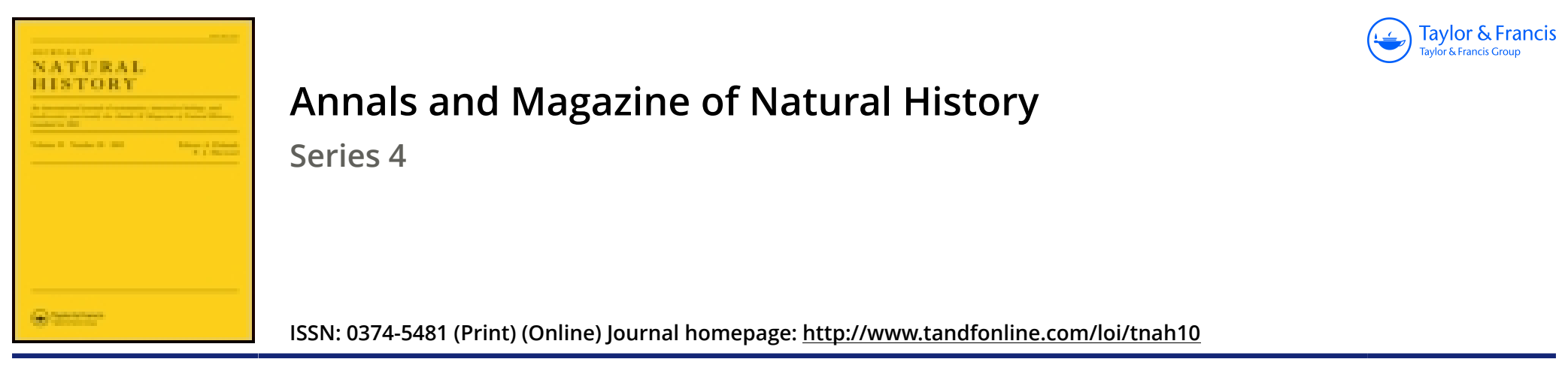

\title{
XVII.-Gigantic squid on the West Coast of Ireland
}

\section{A.G. More}

To cite this article: A.G. More (1875) XVII._Gigantic squid on the West Coast of Ireland , Annals and Magazine of Natural History, 16:92, 123-124, DOI: 10.1080/00222937508681140

To link to this article: http://dx.doi.org/10.1080/00222937508681140

册Published online: 13 Oct 2009.

Submit your article to this journal $\pi$

Џll Article views: 2

Q View related articles $\asymp$

Citing articles: 1 View citing articles 
head 1.45 , ear $0 \cdot 9$, tragus $0.45 \times 0 \cdot 1$, forearm $3 \cdot 4$, thumb $0 \cdot 7$, second finger $5 \cdot 75$, fourth finger $4 \cdot 15$, tibia $1 \cdot 4$, foot and claws $0 \cdot 75$.

This is by far the largest species of the family Vespertilionidæ yet described, its forearm exceeding that of Vesperugo molossus (hitherto known as the largest species) by half an inch, and exceeding by quite one inch the forearm of the largest species of Scotophilus.

Hab. Lagos, west coast of Africa. Type in the collection of the British Museum.

XVII.-Gigantic Squid on the West Coast of Ireland. By A. G. More, Assistant Naturalist in the Museum of the Royal Dublin Society.

Several accounts having Jately appeared in print respecting a very large cuttlefish which was lately captured off Boffin Island, Connemara, I have to offer a few notes made on those portions of the animal which fortunately were preserved by the care of Sergeant O'Connor, and by him forwarded to the Museum in Dublin.

'This giant cuttle or squid was caught on the 25th of April by the crew of a "corragh," a slight narrow rowingboat constructed of hoops and tarred canvas, such as is much used for line-fishing on the west coast of Ireland. The animal was found basking on the surface of the sea, and was attacked by the fishermen, who could not bear to think that so much good bait should be lost. Not until after a laborious chase and some danger, the arms were one by one dissevered, and at last the head. The body, being too unwieldy, was allowed to sink.

From the portions thus brought ashore, Sergeant O'Connor, being much interested in matters relating to fishing-operations and natural history, preserved what he could; and, in this instance, but for lis care the whole prize might have been converted into bait for long-lines. A good part of both tentacles, one short arm, and the great beak entire, with some of the surrounding flesh attached, have reached Dublin; and there remains very little doubt that we have now to deal with a second example of the famous Architeuthis dux of Steenstrup. So little is known of the original specimen, and so imperfect wre the fragments now obtained, that the identification must for the present remain incomplete. Enough, however, remains 
to show that our present specimen is quite distinct from the American Megaloteuthis Harveyi (Kent), which is described as having minute suckers on the margin of the tentacular club. The closely packed small suckers in six rows just below the main suckers of the palm offer another distinctive character, as do also the few small sessile suckers which are scattered along the length of the otherwise smooth peduncle in our specimen.

The following few particulars may be worth placing on record:-

Tentacles 30 feet long when fresh (14 and 17 feet can still be made up from the pickled pieces). A few distant, small, and nearly sessile suckers occur at long intervals along the inner surface of the peduncle. The club, measuring 2 feet 9 inches in its present shrunken state, is occupied in the centre of the palm by two rows of large stalked suckers nearly 1 inch in diameter, fourteen in each row; an alternating row of fourteen smaller suckers ( $\frac{1}{2}$ an inch in diameter) occupies the margin on each side of the palm: thus there are twentyeight large 1-inch suckers in the middle, and the same number of $\frac{1}{2}$-inch suckers along the outside edge. These outer suckers are each armed with a denticulated bony ring of some twentyeight teeth pointing inwards; and no doubt the large inner suckers were similarly furnished; but their rings had fallen out or had been removed before the specimens were examined. Just beneath where the large suckers end there occurs a cluster of small suckers, $\frac{2}{10}$ of an inch in diameter; and these are arranged closely in six transverse rows for about 5 inches along the now narrowing wrist of the club; only a few of the uppermost of these are furnished with denticulate rings; the greater number, like the few small suckers of the peduncle, are sustained by rings with an entire or smooth edge. Above the large suckers of the palm the club tapers upwards, and is again clothed with a great number of small and apparently smooth-ringed suckers.

The short arm is quite spoiled for examination: all the horny rings are gone; and the suckers themselves are scarcely represented. This arm measured 8 feet in length, and 15 inches round the base, when fresh.

The beak has a strong wide tooth about the middle of the edge of the inner mandible, and a much narrower notch on the outer mandible, on each side. The head and eyes were unfortunately lost.

Museum of Royal Dublin Society, July 3, 1875. 